\title{
Presidential Election Laws and Multipartism in Latin America
}

\author{
MARK P. JONES, UNIVERSITy OF Michigan
}

\begin{abstract}
This article examines the interaction between the rules governing presidential elections and multipartism in Latin America. Data from 16 Latin American systems are examined through the use of a multivariate model to gain an understanding of the independent impact of presidential electoral formula (plurality vs. majority), the timing of presidential and legislative elections (concurrent vs. nonconcurrent) and legislative district magnitude on legislative multipartism, and by extension, on the number of relevant political parties operating in the nation. The findings demonstrate the strong and significant impact which formula and timing have on multipartism. They also point to the importance of examining the interaction between elections for different constituent institutions. Finally, they underscore the applicability of Duverger's law to presidential elections.
\end{abstract}

This study examines the interaction between the rules governing presidential elections and multipartism in Latin American political systems. All of the Latin American systems examined here possess presidential systems combined with legislatures which are elected utilizing proportional representation (PR). ${ }^{1}$ I hypothesize that within this framework (Presidential-PR), the rules by which the president is elected have a strong impact on the degree to which the presidential election is a two-party or multi-party contest, the number of effective parties represented in the lower or single house of the national legislature and, by extension, the number of relevant parties operating in the nation. This study focuses on two prominent features of presidential elections: (1) whether the president is elected with a plurality of the vote or whether (at least in the first round) a majority of the popular vote is required for election, and (2) whether the timing of presidential elections is concurrent or nonconcurrent with the election of the nation's lower or single house.

NOTE: I am indebted to John E. Jackson, E. Terrence Jones, Ruth S. Jones, Warren E. Miller, Matthew S. Shugart and two anonymous reviewers for their helpful comments and suggestions. Errors remaining are solely the responsibility of the author.

1 The study examines lower/single houses only (hereafter often referred to as the legislature). 
Previous studies have demonstrated that the level of multipartism in a nation has a significant impact on the level of electoral volatility in that nation (e.g., Remmer 1991). Other studies have discussed the importance of the number of parties for factors such as governmental effectiveness and the representation of interests (e.g., Lijphart 1984; Powell 1982). Most of the scholarly literature which has examined the determinants of multipartism has been based on either parliamentary systems or on presidential systems with legislatures elected utilizing plurality or majority single-member districts. But to study those factors which affect multipartism in Presidential-PR systems such as exist in Latin America, the impact of presidential election laws must be examined. ${ }^{2}$

Shugart and Carey have hypothesized that both the electoral formula used to select the executive and the timing of presidential elections have a noticeable impact on the number of political parties in a nation (Shugart and Carey 1992: 229). They examined the issues of formula and timing using summary statistics from seventeen electoral systems. However, they did not attempt to measure the independent effect of each variable. This study develops a multivariate model (based in part on Shugart and Carey's hypotheses) to examine the independent impact which formula, timing, and legislative district magnitude have on legislative multipartism. This represents both an extension and elaboration of Shugart and Carey's work. The analysis is distinct from their work in three respects. First, and most significantly, in contrast to the serial presentation of statistics employed by Shugart and Carey, a multivariate model is utilized to gain an understanding of the independent impact of formula, timing, and magnitude on multipartism, a subject on which Shugart and Carey did not focus. ${ }^{3}$ Second, the study restricts its analysis to the impact of these variables in Latin American Presidential-PR systems, which not only constitute an overwhelming majority of the world's presidential systems, but also provide a relatively homogeneous population of nations for analysis. Third, five Latin American systems not incorporated in the analysis of Shugart and Carey are included. In sum, through the utilization of a multivariate model, a concentration on one particular set of presidential systems (one that is composed of the modal type of presidential systems), and

2 The premise that legislatures cannot be studied in isolation, particularly in presidential systems, is an underlying theme of a recent work by Shugart and Carey (1992).

3 Two variables were excluded from the analysis after preliminary findings yielded null results. One variable measured the presence or absence of a fused ballot where a single vote registers support for both the presidential and legislative candidates. The other variable measured the use of the highest average d'Hondt formula versus the largest remainders Hare formula for the allocation of the legislative seats. 
the incorporation of additional cases; this article will expand on previous work by seeking to identify the relative salience of formula, timing, and district magnitude for the level of legislative multipartism in an electoral system.

Shugart (1988: 3) has offered the generalization that in presidential systems, "The presidential election imposes a single-seat nationwide district over" the legislative elections. This impact would be expected to be particularly strong in systems where the framework for the election of the president (by plurality or majority formula and with a district magnitude of one) tends to contrast with the rules governing the selection of the legislature (PR from multi-member districts). In Latin America this contrast is present, and moreover, the presidency is generally considered to be the dominant elected constitutional institution. While there has not been a great deal of theoretical work that has examined the relationship between electoral mechanisms across institutions, we can infer from what has been written that there is good reason to expect linkages to exist across these institutional boundaries. Thus we would expect the rules governing the selection of the president to have a strong impact on elections for other elected offices (e.g., the legislature) in Latin American systems.

In his work on majority-runoff and plurality formulae Duverger concluded that "the two ballot majority system tends to produce multipartism" and that "the plurality rule tends to produce a two-party system" (1986: 70). He focused primarily on the mechanical and psychological impact of electoral rules for legislative elections on the number of parties receiving votes for and represented in a legislative body. This article takes Duverger's hypotheses one step futher and examines the psychological impact of plurality versus majorityrunoff elections for the presidency on the number of parties represented in a nation's lower/single house.

This argument that the psychological effect of Duverger's law goes beyond the actual election it governs to affect elections for other political offices is similar in logic to that of Blais and Carty who argued that "[t]he distribution of votes in an election depends on the interaction between voters and parties, and the latter's strategy is as crucial as the former's. Political elites and party leaders will anticipate the mechanical and therefore the psychological effects of electoral systems as much as voters will" (1991: 80). The impact of this interaction between elections for two different institutions which utilize different electoral formulae (plurality/majority versus PR) and different magnitudes (single-member districts vs. multi-member districts) is intriguing. It suggests that there is a second-order effect associated with Duverger's law, with the impact of the rule (primarily the pyschological effect) apparent not only in the presidential elections, but also in the elections for the nations' legislatures. I hypothesize that the psychological effect of either presidential 
election formula permeates the legislative electoral contests; has a strong effect on legislative multipartism; and, by inference, affects other elections in the nation as well as the general configuration of the national party system.

\section{Data, Methodology, and Measures}

The units of analysis for this study are 16 Latin American national electoral systems (see Table 1). The data are the averages for the systems since the goal of the study is to analyze the impact of institutional arrangements on representation and the party system, a task which is best accomplished by examining systems, not individual elections.

三 Table $\mathbf{l}$

Latin American Systems and Their Legislative Elections Included in the Study

\begin{tabular}{|c|c|c|}
\hline Electoral Systems & Years of Legislative Elections Included & \\
\hline Bolivia & $1985, ' 89$ & \\
\hline Brazil lla & $1945, ' 50$ & \\
\hline Brazil Ilb & $1954, ' 58, ' 62$ & \\
\hline Brazil III & 1990 & \\
\hline Chile & $1949, ' 53, ' 57, ' 61, ' 65, ' 69, ' 73$ & \\
\hline Colombia & $1974,{ }^{\prime} 78, ' 82, ' 86, ' 90$ & ?. \\
\hline Costa Rica & 1953, ' 58, ' 62, '66, '70, '74, '78, '82, '86, '90 & \\
\hline Dominican Republic & $1978, ' 82, ' 86,{ }^{\prime} 90$ & \\
\hline Ecuador & $1978-79,84$ & $\because$ \\
\hline El Salvador & 1985, '88, '91 & \\
\hline Guatemala & 1985,90 & 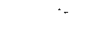 \\
\hline Honduras & 1985,89 & \\
\hline Nicaragua & 1990 & \\
\hline Peru & $1980, ' 85, ' 90$ & \\
\hline Uruguay & $1942,{ }^{\prime} 46, ' 50, ' 66, ' 71, ' 84, ' 89$ & \\
\hline Venezuela & $1958, ' 63, ' 68,73,78, ' 83, ' 88$ & \\
\hline
\end{tabular}

Note: Brazil IIa and IIb represent the concurrent and nonconcurrent systems respectively of the Brazilian Second Republic while Brazil III is the Brazilian Third Republic (for more information see note 7 ).

(For information on the sources for the data used, see Tables 2 and 3.) There were two criteria which had to be met for a system to be included in this study. First, the nation had to be a democracy, a nation being considered democratic if its government has been elected via open and competitive elections. ${ }^{4}$ A second criterion was that the systems be amenable to analysis using

4 The merits of this institutional approach toward the classification of democratic systems have been discussed by Diamond, Linz, and Lipset (1990: 6-9) as well as by 
the measures employed in the study. ${ }^{5}$ Ordinary least squares (OLS) regression analysis, with a $\log$-log functional form assumed to exist between the independent and dependent (i.e., multipartism) variables, is employed

Electoral formula is operationalized as a binary variable with the system scored 0 if the executive is elected by a plurality vote (i.e., a relative majority in which the candidate/party receiving the most votes in the first and only round of voting wins the election) and 1 if the executive must receive an absolute majority (over 50 percent of the popular vote) in the first round to be elected. In the majority systems, if no candidate receives a majority in the first round a runoff between the top two challengers is used in five of the seven majority systems to select the president; in two systems however (Bolivia and Chile), the president is then chosen by a majority vote in the legislature (with the upper and lower chambers meeting in joint session). ${ }^{6}$

Remmer (1991). Remmer succinctly summarizes the logic of this institutional approach: "Following the conventions established in the study of Latin American politics over the course of the past two decades, democratic governance is defined here strictly in institutional terms, leaving open to empirical investigation questions regarding the consequences of competitive institutions for popular participation in policy formation, socioeconomic equity, and other political outcomes" (1991: 796).

5 The Argentine system is excluded from analysis due both to its use of an electoral college, which is distinct from either a plurality or majority system, and to the system's employment of both concurrent and nonconcurrent legislative elections. Colombia is excluded from the multivariate portion of the analysis because legislative elections occur an average of three months prior to the presidential elections and are thus neither concurrent nor purely nonconcurrent. Elections for Uruguay which occurred during that nation's brief post-World War II experience with a collegial executive (1952-66) are excluded from analysis.

6 Unlike the case in the pure plurality systems, the Costa Rican constitution specifies that to be elected a candidate must receive more than 40 percent of the vote. Costa Rica is however classified as a plurality system due to the low level of this threshold which makes the system much more similar to plurality than majority systems. It should be noted that in the 10 presidential elections which have occurred under the Costa Rican 1949 constitution, at no time has this 40 percent threshold not been surpassed. The Peruvian constitution specifies that to be elected in the first round of voting a presidential candidate must receive over 50 percent of the vote. For the 1980 election a one-time exception lowered this threshold to 36 percent. Nevertheless, Peru is coded as a majority system. Both Bolivia and Chile (only the pre-1973 system is examined) are coded as majority systems. Theoretically Bolivia and Chile are considered to be similar in their functioning to the majority-runoff systems. Like the majority-runoff systems, both require that for a candidate to be elected in the first round he or she has to receive an absolute majority of the popular vote and, also similar to the runoff systems, a choice is made in the second round among the top finishers (two in all of the runoff systems and Chile and three in Bolivia). 
Timing is operationalized as a binary variable with concurrent presidential and legislative elections being scored as a 0 and nonconcurrent presidential and legislative elections scored 1 . Concurrent elections are defined as elections where the first or only round of the presidential election and the election of the legislature are held on the same day. Nonconcurrent elections are defined as elections where the popular selection of the legislature occurs in a separate year from the election of the president. ${ }^{7}$ Average district magnitude (i.e., the average number of representatives per electoral district) is calculated by dividing the number of legislative seats by the number of legislative districts. ${ }^{8}$

Legislative multipartism is calculated utilizing a measure based on the percentage of legislative seats won by the various parties in the lower/single house elections (i.e., Laakso and Taagepera's measure of the "effective number of parties" in a party system [1979: 3-27]). ${ }^{9}$ Legislative multipartism was used instead of the most prominent alternative, electoral multipartism, for two reasons..$^{10}$ First, it better reflects party representation at the governmental

7 For Ecuador, only the 1978-79 and 1984 elections are included in the analysis. During the period 1978-84 the Ecuadoran system had only concurrent presidential and legislative elections. In 1979 the district-level legislative elections were held concurrently with the presidential runoff while in 1984 they were held contemporaneously with the first round of the presidential elections. Beginning in 1986 Ecuador also employed midterm elections for the district-level congressional deputies which renders the post1984 Ecuadoran system un-amenable to the analysis used in this study. In the Brazilian Second Republic the first two presidential and legislative elections $(1945,1950)$ were held concurrently, while the latter three elections for the legislature $(1954,1958,1962)$ were held separately from the presidential elections. The Brazilian Second Republic was divided into two separate systems: Brazil IIa which represents the elections of 1945 and 1950, and Brazil IIb which represents the elections of 1954, 1958, and 1962.

8 In four cases complex districting occurs. In Guatemala and Ecuador separate elections are held at the district and national level; in El Salvador a two-tiered district framework is employed (in 1991 only); and in Venezuela compensatory seats are allocated to minor parties. Aided by the work of Taagepera and Shugart (1989: 269), an "effective" magnitude was constructed for each system based on the geometric average of the magnitude of the systems' two levels or tiers. A similar transformation was conducted for those systems which require that a party win a full electoral quotient in order to be eligible to receive any seats in an electoral district (i.e., Bolivia in 1989 only, Brazil lla, Brazil IIb, Brazil III).

9 The equation used for the measure of legislative multipartism $(N)$ is: $N=1 /(1-F)$, where $\mathrm{N}$ represents the "effective number of parties," $\mathrm{F}$ represents the index of fractionalization, and $F=1$ - the sum of the squared seat shares of each party. Since a log-log functional form is employed (using logarithims to the base 10), the log values of the legislative multipartism and average district magnitude measures are used in the quantitative analysis.

${ }^{10}$ Electoral multipartism measures the effective number of parties in a system based on 
level, and hence the existence of relevant parties (though at the cost of overlooking the presence of very minor parties). Second, it allows for the inclusion of four systems which could not be analyzed if electoral multipartism were employed. ${ }^{11}$ In any event, analysis of the available data revealed electoral and legislative multipartism to be highly correlated (R-.97 for 11 cases), with legislative multipartism consistently lower than electoral multipartism for all systems.

The values for the multipartism variable have a reasonably continuous distribution, with a mean of 3.71 effective parties and a standard deviation of 1.73. Values for this dependent variable range from a low of 2.05 (which is the value for Nicaragua and corresponds to a little more than two effective parties) to a high of 8.62 (which is the value for Brazil III and corresponds to roughly eight and two-thirds effective parties). This distribution is illustrated graphically in Table 2.

三 Table 2

Legislative Multipartism in 16 Latin American Electoral Systems

"Effective Number of Parties" in the Lower/Single House of the National Legislature*

\begin{tabular}{cccccccc}
\hline \multirow{3}{*}{ ELECTORAL } & $2.00-2.50$ & $2.51-3.00$ & $3.01-3.50$ & $3.51-4.00$ & $4.01-4.50$ & $4.51-5.00$ & $5.01-$ \\
SYSTEMS & Nicaragua & El Salvador & Venezula & Guatemala & Bolivia & Brazil IIb & Chile \\
& Honduras & Unuguay & Brazil lla & & & Ecuador & Brazil III \\
& Colombia & Peru & & & & & \\
& Costa Rica & & & & & & \\
& Dom Republic & & & & & & \\
\end{tabular}

* This is Laakso and Taagepera's (1979) "Effective Number of Parties" measure. For more information on its calculation, see note 9 .

Sources: Archer 1991; Chang Mota 1986; CINAS 1991; Contreras 1986; Council of Freely Elected Heads of Government 1990; Darlić Mardesić 1987; Delgado Fiallos 1986; Fabregat 1950, 1957, 1964; Hernández Valle 1986; Honorable Corte Nacional Electoral 1990; Inforpress Centroamericana (Guatemala City), 11 January 1991, 4; International Foundation for Electoral Systems 1992; Inter-Parliamentary Union 1981-1990; Jiménez et al. 1988; Jones 1993; Leonard and Natkiel 1986; Listin Diario (Santo Domingo), 12 June 1990, 12; Mainwaring 1994; McDonald and Ruhl 1989; Tribunal Supremo de Elecciones 1990; Urzúa Valenzuela 1986; Wells 1966a, 1966b.

the votes won by each party in an election, as opposed to legislative multipartism which is derived from the number of seats won by each party in an election.

11 The Brazilian Second (Ila and Ilb) and Third Republics and Peru would have to be excluded if electoral multipartism were used. The widespread use of alliances in Brazil where the vote is often recorded for the alliances, not the parties, prevents the use of the Brazilian Second (IIa and IIb) and Third Republics. Lack of adequate vote data for a majority of the Peruvian elections precludes the examination of electoral multipartism for Peru. 
Finally, the degree to which the presidential elections of a system conform to a two-party framework is measured by summing the percentage of the valid popular vote won by the top two candidates in the elections most closely corresponding to those of the legislative elections examined in this study. This measure is preferable to the "effective number of parties" measure since the question being asked is whether the system conforms to a two-party system, not how many parties compete in the election.

\section{Data Analysis}

\section{Plurality versus Majority Presidential Electoral Systems}

The distinction between plurality and majority systems has been a relatively understudied aspect of electoral systems (Riker 1986: 28). Work in this area by Duverger, most rational choice theorists, and to a lesser extent Riker, does however provide support for the hypothesis that whereas plurality elections tend to result in two-party systems, majority-runoff elections tend to lead to multi-party systems (Shugart 1988: 2). Furthermore, Riker's corollaries to Duverger's law do not seem to apply to Latin American presidential elections (Riker 1986: 32). First, the election is a national one and thus Riker's corollary involving parties which are third nationally but one of the top two locally is not relevant. Second, the presence of a Condorcet winner at the presidential level in Latin American systems is doubtful, given the fact that the executive office has been occupied by more than one party in all of the systems included in the study during the period of analysis. This reality is inconsistent with the hypothesis of a Condorcet winner in any of the systems in the study. If any nation approached this level it would have been Chile in the 1960s with the potential of the Christian Democrats becoming a Condorcet party between the left and right; this of course did not occur. In the presidential election of 1970, Chileans elected the Socialist Salvador Allende who "would not have received a majority of the vote in a two-way race" (Valenzuela 1978: 42).

The formula used to elect the president is hypothesized to have a strong impact on the number of parties in a nation's legislature. This strong impact is considered to be the product of an interaction between the rational actions of individuals who do not want to waste their votes in plurality elections (with this factor indirectly influencing their vote choice in legislative elections, in part by limiting the voters' realistic alternatives in the voting booth) and the rational actions of party leaders who in plurality presidential electoral systems tend to coalesce into larger parties than is the case in majority presidential systems, since the principal electoral prize, the presidency, goes to the plurality winner. Thus, given the regular occurrence of presidential elections (in the absence of a Condorcet winner) there is less incentive in plurality (as 
opposed to majority) systems for most politicians to form alternative parties whose probability of capturing the presidency is quite low.

This dynamic has been identified by Shugart and Carey as being linked to strategic decisions of political elites in response to the electoral formula used to select the executive. In plurality systems there exists a tendency among party elites to "form a broad coalition behind the front-runner" as well as when in opposition "to coalesce behind one principal challenger" (Shugart and Carey 1992: 209). This contrasts with the majority-runoff systems which "actually discourage the coalescence of opposing forces," with political elites making the decision to run their own presidential candidates with the goal of either finishing in the top two in the first round, or else demonstrating an electoral following that can be delivered in the runoff election to one of the top two finishers in exchange for selective benefits in the future (ibid.: 210). Strategic bargaining occurs among relevant political actors in all of the Latin American presidential elections. When this bargaining occurs however depends to a great extent on the electoral formula employed. In plurality systems it takes place prior to the election whereas in majority systems it occurs after the first round of elections (ibid: 216). Consolidation prior to the election as occurs in the former systems should result in a lower level of presidential, and indirectly legislative, multipartism than should the post-first round bargaining which occurs under the majority framework.

The sixteen Latin American systems examined are almost evenly split between those which utilize a plurality selection process to select their executive (nine) and those that employ a majority system to select their executive (seven). Due to the assumed differential psychological impact of plurality versus majority systems on both rational voters and rational party leaders, we would expect plurality presidential elections to be dominated by two parties, with the first round of the majority system elections involving strong competition among multiple parties. This premise is confirmed by an initial analysis of data for presidential elections corresponding to the legislative elections included in the study. ${ }^{12}$ Presidential elections in the plurality systems tend to be dominated by two parties, with the top two in the plurality systems averaging 86.86 percent of the vote as opposed to the majority systems where the top two parties average only 62.60 percent of the vote in the first round. This relationship is illustrated graphically in Table 3 with the plurality systems concentrated in the upper ranges and the majority systems falling (though with less regularity) at the lower end of the scale. ${ }^{13}$

12 For Ecuador results from the 1988 and 1992 presidential elections (in addition to those from 1978 and 1984) were used in this portion of the analysis.

13 An anonymous reviewer suggested that the anomalous status of El Salvador and Chile 
Table 3

Percentage of the Valid Popular Vote Received by the Two Leading Parties in First Round Presidential Elections for 15 Plurality and Majority Latin AmerlCAN SYSTEMS

\begin{tabular}{|c|c|c|c|c|c|c|}
\hline \multirow{2}{*}{$\begin{array}{l}\text { Presidential } \\
\text { Elecrion } \\
\text { Formula }\end{array}$} & \multicolumn{6}{|c|}{ Percentage of the Vote Received by the Two Leading Parties in the First Round of Elections } \\
\hline & $100-90$ & $89.5-80$ & $79.5-70$ & $69.5-60$ & $59.5-50$ & $49.5-40$ \\
\hline Plurality & $\begin{array}{l}\text { Nicaragua } \\
\text { Honduras } \\
\text { Costa Rica }\end{array}$ & $\begin{array}{c}\text { Colombia } \\
\text { Dom Republic } \\
\text { Uruguay }\end{array}$ & $\begin{array}{c}\text { Venezuela } \\
\text { Brazil II }\end{array}$ & & & \\
\hline Majority & & El Salvador & $\begin{array}{l}\text { Chile } \\
\text { Peru }\end{array}$ & & $\begin{array}{c}\text { Bolivia } \\
\text { Guatemala } \\
\text { Ecuador }\end{array}$ & Brazil IIl \\
\hline
\end{tabular}

Sources: Europa Publications Limited 1978-1991; Jornal do Brasil, 22 November 1989; Keesing's 1974-1992; McDonald 1971; Ruddle and Gillette 1972. For additional sources see Table 2.

The basic multivariate analysis combines the hypothesis of Duverger (that plurality elections lead to two-party systems while majority systems favor multi-party systems) with Shugart's assertion that presidential elections can have a strong impact on legislative elections in presidential systems. The result is a prediction that, holding other factors constant, systems which utilize the plurality presidential electoral formula will have lower levels of legislative multipartism than will systems that employ the majority formula. ${ }^{14}$ By extension, and using legislative multipartism as a proxy for the national party system, this choice of presidential election formula is hypothesized to influence the number of effective parties in the nation as well.

As is seen in the OLS regression results presented in Table 4, the presidential election formula (plurality or majority) does have a very strong impact on the number of effective parties in the legislature, with a t-ratio (2.371, $11-\mathrm{df}$ ) which is significant at less than .05 for a one-tailed test. ${ }^{15}$

could be due to their use of nonconcurrent elections. These legislative elections might be used by parties to test their electoral strength, with weaker parties then joining with other (perhaps stronger) parties to support a common candidate in the next presidential contest. Subsequent analysis suggested that such a process did not occur in $\mathrm{El}$ Salvador and was only partially present in Chile (where the timing of municipal elections was also important in this regard).

14 A slightly different version of this hypothesis is offered by Shugart and Carey (1992: 224-25).

15 The possibility of the existence of multicollinearity, especially between the formula and 
Table 4

Ordinary Least Squares Estimates of Institutional Determinants of Legislative MulTipartism

Exponential of

Independent Variables Estimated Coefficient Estimated Coefficient \# T-Ratio (11 DF)

$\begin{array}{llll}\text { Presidential Formula } & 0.176 & 1.500 & 2.371^{*} \\ \text { Election Timing } & 0.155 & 1.429 & 1.924^{*} \\ \text { District Magnitude } & 0.148 & & 1.408 \\ \text { Constant } & 0.256 & & 2.008^{*} \\ \text { R-Square }=.563 & & \\ \text { *p }<.05 \text { one-tailed test } & & \\ \text { Note: a Log-Log functional form is employed. } & & \end{array}$

\# Note that the exponential of the estimated coefficient indicates the ratio of the expected value of $Y$ (i.e., the dependent variable multipartism) when the binary variable (either presidential formula or election timing) equals one to the expected value of $Y$ when the binary variable equals zero. The district magnitude variable coefficient (as is the case with all continuous variables) is interpreted via its elasticity. In a log-log model however, one cannot interpret the binary variable coefficients using their elasticities, and thus for purposes of interpretation, the exponentials of the estimated coefficients of the binary variables are employed. For more information on the interpretation of these coefficients, see notes 16 and 17 .

Sources: See sources listed in Table 2.

Here, the presence of a majority system results in a level of multipartism which is 1.500 times the level of multipartism of a plurality system (holding other factors constant). ${ }^{16}$ For example, based on this model, in the Dominican Republic (multipartism: 2.46 , with a plurality formula and concurrent timing) a 50 percent increase in multipartism from 2.46 to 3.69 would make the Dominican Republic's level of multipartism comparable to that of Guatemala (multipartism: 3.80, majority formula and concurrent timing). This change would amount to an increase of roughly one and one-fourth effective parties in the legislature and to a three-column shift to the right in Table 2.

timing variables, was examined. These tests revealed low R-Squares when each independent variable was regressed on all of the other independent variables, with the highest R-Square being .182 (Lewis-Beck 1980: 58-62).

161.500 is merely the exponential of the estimated coefficient (i.e., Exponential .176 1.500 ). The value 1.500 indicates that the expected value of the multipartism variable, when the presidential formula variable equals one (i.e., a majority system), is 1.500 times the expected value of the multipartism variable when the presidential formula variable equals zero (i.e., a plurality system). Since logarithims to the base 10 are employed, this exponential is given by 10 raised to the power of the estimated coefficient $(0.176)$ for the formula variable. I am indebted to John E. Jackson for his advice regarding the general use and interpretation of dummy variables in a log-log model 
In sum, these data in Table 3 and 4 provide strong support for the hypothesis that the presidential electoral formula has a noticeable impact on both the number of parties effectively competing in presidential elections as well as on the number of effective parties represented in the legislature and by extension in the nation. This implies that rules for elections for one constitutional office have an impact on the nature of elections and representation in other elective bodies.

\section{Concurrent versus Nonconcurrent Presidential and Legislative Elections}

There is strong theoretical support for the hypothesis that in Presidential-PR systems the timing of presidential and legislative elections has a significant impact on the level of multipartism in the latter elections (Shugart and Carey 1992: 226-53). Concurrent systems should be expected to have lower levels of multipartism than is the case when the two elections are held at different times when the restraining impact of the executive selection process is much weaker.

Multivariate analysis provides solid support for the hypothesis that election timing has a strong impact on legislative multipartism, with a t-ratio $(1.924,11-\mathrm{df})$ which is significant at less than .05 for a one-tailed test. Table 4 indicates that the use of nonconcurrent elections results in a level of multipartism that is 1.429 times the level of multipartism that occurs when concurrent elections are used (holding other factors constant). ${ }^{17}$ Here the model indicates that a 42.9 percent increase in multipartism in a system such as Venezuela (multipartism: 3.18, plurality formula and concurrent timing) would lead to an increase in multipartism from 3.18 to 4.54 . This change would result in a transformation of Venezuela's party system (with slightly more than three effective parties) to a situation very similar to that of Brazil IIb (multipartism: 4.54, plurality formula and nonconcurrent timing), with the difference being the presence of roughly one and one-third more effective parties in the legislature. On Table 2 this change would shift Venezuela three columns to the right.

Analysis of Argentina's system which experiences both concurrent and nonconcurrent presidential and legislative elections provides further support for the salience of timing for multipartism. In the concurrent elections Argentina

17 Similar to the case of the presidential formula variable, the value 1.429 indicates that the expected value of the multipartism variable, when the election timing variable equals one (i.e., a nonconcurrent system), is 1.429 times the expected value of the multipartism variable when the election timing variable equals zero (i.e., a concurrent system). This ratio is given by 10 raised to the power of the estimated coefficient (0.155) for the timing variable. 
had levels of legislative multipartism which were much lower than the multipartism of the nonconcurrent elections ( 2.39 vs. 2.62). ${ }^{18}$ These results provide support for Shugart's previous findings and demonstrate the salience of election timing for multipartism in a nation.

\section{District Magnitude}

In an examination of 31 Anglo-European systems Arend Lijphart (1990: 488) detected a small positive relationship between district magnitude and electoral multipartism. A replication of Lijphart's study using data from twentytwo Latin American and Caribbean nations revealed the same positive relationship, albeit in an even more limited status (Jones 1993: 66).

Table 4 reveals the impact of district magnitude on legislative multipartism to be in the hypothesized direction, but not significantly strong. The estimated coefficient $(0.148$, t-ratio: $1.408,11-\mathrm{df})$ does however reveal that district magnitude influences legislative multipartism to a certain extent. This finding should not be taken to imply that district magnitude is not a very important structural factor in other contexts. For example, Lijphart (1985, 1990), Taagepera and Shugart (1989), and others have repeatedly demonstrated the strong salience of magnitude for the degree of proportionality of an electoral system.

\section{Discussion}

Four important conclusions can be drawn from this study. First, Duverger's law does apply to presidential systems. The data clearly demonstrate that Latin American systems which employ a plurality system to elect their president have presidential elections which correspond much more closely to those of a two-party system than do those systems which utilize a majority framework and thus tend to have a larger number of parties effectively competing in presidential elections. Second, the choice between a plurality and majority presidential election formula has a strong impact on the level of legislative multipartism and, by inference, on the number of relevant parties in the nation's party system. Plurality systems clearly possess lower levels of legislative multipartism than do majority systems. Third, Shugart's hypothesis regarding the salience of presidential and legislative election timing was supported by these data. Systems in which these elections were held concurrently have lower levels of multipartism than do those systems where these two elections were held at separate times. Finally, district magnitude was found to

18 Argentina had concurrent presidential and legislative elections in 1983 and 1989 , and nonconcurrent legislative elections in 1985, 1987, and 1991. The source for these data is the files of the Argentine Ministerio del Interior, Dirección Electoral Nacional, Departamento de Estadísticas. 
have only a modest impact on multipartism, with the finding in the hypothesized direction (positive), but not significant. ${ }^{19}$

The focus of this article has been on the impact of presidential electoral rules on elections for the legislature. However, the potential impact of legislative electoral arrangements on presidential multipartism should be kept in mind (Shugart and Carey 1992: 240). When examining the impact of legislative election rules on presidential multipartism, one crucial variable is the electoral formula, in particular the differential impact of PR formulae versus the plurality formula. This variable, held constant in the Latin American cases, probably goes a great distance in explaining the lower level of presidential multipartism in Presidential-Plurality systems (e.g., Philippines 1946-69, United States) than in the Presidential-PR systems.

The findings of this study point to the importance of examining the interaction between elections for different constituent institutions. In at least two instances (formula and timing) the electoral rules governing the selection of the chief executive in presidential systems have a strong impact on the degree of multipartism in a nation's legislature and, more generally, on the number of relevant parties operating in a nation's party system. These effects are both proximal and distal in nature, affecting both the results of the actual elections and (potentially) the long-term nature of a nation's party system. ${ }^{20}$ The increasing popularity of the Presidential-PR and Premier-Presidential-PR frameworks in Eastern Europe, Africa, and Asia (e.g., Namibia, Poland, Romania, Senegal, Sri Lanka), as well as the Presidential-PR system's continued presence in Latin America, begs for a more complete understanding of the interaction between the rules governing the selection process for the systems' two most important constituent units (the presidency and the lower/single house). ${ }^{21}$

19 While most of the results reported were quite strong, given the strength of the theoretical argument, why were they not stronger? A partial explanation would be based around four points: (1) many of the systems have only experienced a few elections under the current rules, and it may take time for both voters and party elites to conform to the electoral rules through a learning process; (2) there are many electoral rules (e.g., rules on party formation) which were not examined here but may influence the level of multipartism in specific systems; (3) the small size of the population examined increases the probability of partial outliers exerting a strong influence on the results; and (4) many other factors (e.g., socioeconomic, religious, cultural, regional, ethnic) can also affect the level of multipartism in a nation.

20 The political consequences of the number of legislative parties in an electoral system is an important topic of inquiry. It is, however, beyond the scope of this article. For a discussion of some important consequences, see Lijphart (1984), Powell (1982), Remmer (1991), and Shugart and Carey (1992).

21 A majority of the more recent presidential systems are of the Premier-Presidential type. While the same basic systemic effects which occur in the Presidential-PR systems are 
This research has demonstrated the relevance of presidential electoral frameworks for the partisan configuration of a nation's legislature. It has provided support both for previous work that examined the system-wide importance of certain presidential electoral arrangements for lower level elections as well as for work which identified the salience of Duverger's psychological effect for the conduct of elections. Furthermore, it is apparent that the choice of rules governing presidential elections is important not only for the outcome of the election of the chief executive, but also for the elections of other representative bodies, particularly the national legislature. These points should therefore be incorporated into any discussion of presidential systems as well as into any consideration of constitutional revisions or constructions, such as are occurring in the 1990s throughout the world.

\section{REFERENCES}

Archer, Ronald P. 1991. Unpublished manuscript. Durham, NC: Duke University. Blais, André, and R. K. Carty. 1991. "The Psychological Impact of Electoral Laws: Measuring Duverger's Elusive Factor." British Journal of Political Science 21: 79-93.

Centro de Investigación y Acción Social (CINAS). 1991. El Salvador Boletín de Análisis e Información, \#7.

Chang Mota, Roberto. 1985. El Sistema Electoral Venezolano: Su Diseõo, Implantación y Resultados. Caracas: Consejo Supremo Electoral.

Contreras, Dario. 1986. Comportamiento Electoral Dominicano: Elecciones Dominicanas 1962-1982. Santo Domingo: Editora Corripio.

Council of Freely Elected Heads of Government. 1990. Observing Nicaragua's Elections 1989-90. Special Report \#1, Atlanta, GA: The Carter Center of Emory University.

Darlić Mardesić, Vjekoslav. 1987. Estadisticas Electorales de Ecuador 1978-1987. Quito: ILDIS.

Delgado Fiallos, Anibal. 1986. Honduras Elecciones (Más allá de la fiesta civica) 85. Tegucigalpa: Editorial Guaymuras.

Diamond, Larry, Juan J. Linz, and Seymour Martin Lipset, eds. 1990. Politics in Developing Nations: Comparing Experiences with Democracy. Boulder, CO: Lynne Reiner.

Duverger, Maurice. 1986. "Duverger's Law: Forty Years Later." In Bernard Grofman and Arend Lijphart, eds., Electoral Laws and Their Political Consequences. New York: Agathon Press.

Europa Publications Limited. 1978-1988. The Europa Year Book. London: Europa Publications Limited.

also hypothesized to hold true in these sytsems, the fact that the two represent two distinct systems should not be obscured. I thank Matthew Shugart for clarifying this point for me. 
1989-1991. The Europa World Year Book. London: Europa Publications Limited.

Fabregat, Julio T. 1950. Elecciones Uruguayas: Febrero de 1925 a Noviembre de 1946. Montevideo: Republica Oriental de Uruguay, Poder Legislativo.

1957. Elecciones Uruguayas de Noviembre de 1950 a Noviembre de 1954. Montevideo: Republica Oriental de Uruguay, Camara de Representantes.

- 1964. Elecciones Uruguayas de 25 de Noviembre 1962. Montevideo: Republica Oriental de Uruguay, Camara de Senadores.

Hernández Valle, Ruben. 1986. Costa Rica: Elecciones de 1986, Análisis de los Resultados. San Jose, Costa Rica: IIDH-CAPEL.

Honorable Corte Nacional Electoral. 1990. Elecciones Generales 1985-1989. La Paz: Honorable Corte Nacional Electoral.

Inforpress Centroamericana (Guatemala City). 1991. Central America Report 11 January.

International Foundation for Electoral Systems. 1992. Unpublished foundation country data files.

Inter-Parliamentary Union. 1981-1990. Chronicle of Parliamentary Elections and Developments. Geneva: International Centre for Parliamentary Documentation. Jiménez, Edgar C., et al. 1988. El Salvador: Guerra, Política y Paz (1979-1988). San Salvador: CINAS.

Jones, Mark P. 1993. "The Political Consequences of Electoral Laws in Latin America and the Caribbean." Electoral Studies 12: 59-75.

Jornal do Brasil, 1989, 22 November.

Keesing's. 1974-1992. Keesing's Contemporary Archives. Bristol: Keesing's.

Laakso, Markku, and Rein Taagepera. 1979. "Effective Number of Parties: A Measure With Application to West Europe." Comparative Political Studies 12: 3-27.

Leonard, Dick, and Richard Natkiel. 1986. World Atlas of Elections: Voting Patterns in 39 Democracies. London: The Economist Publications Limited.

Lewis-Beck, Michael S. 1980. Applied Regression: An Introduction. Newbury Park, CA: Sage.

Lijphart, Arend. 1984. Democracies: Patterns of Majority and Consensus Rule in Twenty-One Countries. New Haven, CT: Yale University Press.

_. 1985. "The Field of Electoral Systems Research: A Critical Survey." Electoral Studies 4: 3-14.

_. 1990. "The Political Consequences of Electoral Laws, 1945-85." American Political Science Review 80: 481-96.

Listin Diario (Santo Domingo), 1990, 12 June, p. 12.

Mainwaring, Scott. 1994. "Brazil: Weak Parties, Feckless Democracy." In Scott Mainwaring the Timothy Scully, eds., Building Democratic Institutions: Parties and Party Systems in Latin America. Stanford, CA: Stanford University Press.

McDonald, Ronald H. 1971. Party Systems and Elections in Latin America. Chicago: Markham.

McDonald, Ronald H., and J. Mark Ruhl. 1989. Party Politics and Elections in Latin America. Boulder, CO: Westview Press. 
Powell Jr., G. Bingham. 1982. Contemporary Democracies: Participation, Stability, and Violence. Cambridge, MA: Harvard University Press.

Remmer, Karen L. 1991. "The Political Impact of Economic Crisis in Latin America." American Political Science Review 85: 777-800.

Republica Argentina. Ministerio del Interior. Dirección Electoral Nacional. Departamento de Estadísticas. Department data files.

Riker, William H. 1986. "Duverger's Law Revisited." In Bernard Grofman and Arend Lijphart, eds., Electoral Laws and Their Political Consequences. New York: Agathon Press.

Ruddle, Kenneth, and Philip Gillette, eds. 1972. Latin American Political Statistics. Los Angeles: Latin American Center, University of California, Los Angeles.

Shugart, Matthew S. 1988. "Duverger's Rule, District Magnitude, and Presidentialism." Ph.D. dissertation, University of California, Irvine.

Shugart, Matthew Soberg, and John M. Carey. 1992. Presidents and Assemblies: Constitutional Design and Electoral Dynamics. Cambridge: Cambridge University Press.

Taagepera, Rein, and Matthew Soberg Shugart. 1989. Seats and Votes: The Effects and Determinants of Electoral Systems. New Haven, CT: Yale University Press.

Tribunal Supremo de Elecciones. 1990 Cómputo de Votos y Declatorias de Eleccion1990. San Jose, Costa Rica: Imprenta Nacional.

Urzúa Valenzuela, Germán. 1986. Historia Política Electoral de Chile 1931-1973. Santiago de Chile: Tarmacos.

Valenzuela, Arturo. 1978. "The Breakdown of Democratic Regimes: Chile." In Juan J. Linz and Alfred Stepan, eds., The Breakdown of Democratic Regimes. Baltimore, MD: Johns Hopkins University Press.

Wells, Henry, ed. 1966a. Costa Rica Election Factbook: February 6, 1966. Washington, DC: Institute for the Comparative Study of Political Systems.

- 1966b. Uruguay Election Factbook: November 27, 1966. Washington, DC: Institute for the Comparative Study of Political Systems.

Received: September 23, 1992

Accepted for Publication: March 10, 1993 